\section{Hygienic and sensory quality factors affecting the shelf-life of Fruhe (Casu axedu) tradi- tional Sardinian fresh cheese}

\author{
Carlo Spanu, ${ }^{1}$ Christian Scarano, ${ }^{1}$ \\ Massimiliano Venusti, ${ }^{2}$ Daniela Sardo, ${ }^{2}$ \\ Salvatore Serra, ${ }^{2}$ Michela Ibba, ${ }^{1}$ \\ Fabio Frau, ${ }^{1}$ Enrico P.L. De Santis ${ }^{1}$ \\ 'Dipartimento di Medicina Veterinaria, \\ Università di Sassari; ${ }^{2}$ Agenzia LAORE \\ Sardegna, Dipartimento per le Produzioni \\ Zootecniche, Servizio Produzioni \\ Zootecniche, Sassari, Italy
}

\section{Abstract}

A study was conducted to evaluate the durability of the traditional fresh soft cheese Fruhe manufactured in Sardinia either from goats' or sheep's milk. Four farmstead cheese-making plants were visited three times during the Fruhe cheese-making season. During each visit environmental samples were collected from food contact and non-food contact surfaces in order to evaluate the presence of Enterobacteriaceae, Escherichia coli, Pseudomonas spp. and Listeria spp. In a total of 60 environmental samples, Escherichia coli and Listeria spp. were never detected, while contamination with Enterobacteriaceae and Pseudomonas spp. was observed respectively in $48 \%$ and $43 \%$ of samples. The microbiological profile of 48 Fruhe cheese samples was assessed at different time points during the product shelf-life. Aerobic mesophilic bacteria, Enterobacteriaceae, E. coli, Pseudomonas spp., Bacillus cereus and Listeria monocytogenes were investigated at $0,7,14$ and 21 days after production. E. coli, L. monocytogenes and $B$. cereus were never detected in the product. Enterobacteriaceae contamination was observed, showing decreasing levels over time. Pseudomonas spp. was recovered in only two Fruhe samples (3.3\%) at day 0. Sensory analysis was also conducted using a triangle test to determine whether a difference between Fruhe samples at 14 and 21 days of shelf-life exists. Based on the evolution of the microbiological profile and the sensory attributes observed in the present study, it is reasonable to assume that the product shelf-life can be feasibly extended up to 21 days.

\section{Introduction}

The terms Fruhe and Casu axedu are used to refer to a traditional soft fresh cheese manufactured in Sardinia (Italy) from pure cows', sheep's, goats' milk or from a mixtures of these. It is also known with many other synonyms according to the different areas of production in the regional territory. The name Merca indicates the cheese aged in brine. The production of Fruhe is typically conducted at artisanal level or in farmstead cheese-making facilities. Although Fruhe manufacturing process may vary from producer to producer, it is usually obtained from whole raw or heattreated milk. Lactic acid bacteria (LAB) are added with natural or commercial starter culture and the milk is coagulated with liquid calf or kid rennet or lamb paste rennet. Clotting occurs into plastic containers within 15-30 min, while hardening of the curd takes up to 45 h (LAORE Sardegna, 2013). In order to aid the syneresis, the curd is then cut into slices and the excess of whey discarded. After $24 \mathrm{~h}$ ripening, the containers are sealed with a plastic film and the Fruhe is stored at refrigeration temperature. The final product is a fresh compact coagulum with sour taste and with the typical flavour of the milk of the species of origin. It is presented in rectangular blocks of variable size and weight (about $500 \mathrm{~g}$ ), immersed in the residual whey. The shelf-life is defined under the responsibility of the food business operator and varies from 10 days up to 2 weeks under refrigerated storing conditions.

Regulation (EC) No 852/2004 (European Commission, 2004) on the hygiene of foodstuffs states that the primary responsibility for food safety rests with the food business operators (FBOs), which are legally responsible for the determination of the date of minimum durability of the foodstuffs they place on the market. FBOs are also responsible for the compliance of the foodstuffs with microbiological criteria defined by Regulation (EC) No 2073/2005 (European Commission, 2005). Contamination of the environment where food is prepared is recognised as an important transmission route of microorganism in readyto-eat foods (Health Protection Agency, 2009). Testing the food environment to monitor the presence of spoilage and pathogen microorganisms is an essential strategy to verify whether good hygienic practices (GHP) are correctly applied (Tompkin et al., 1999). Indicator microorganisms, such as Enterobacteriaceae and Escherichia coli, are frequently used as a measure of the effectiveness of sanitation in a food processing environment and they can also be used to assess post-process contamination in ready-to-eat foods (Jay, 1992; Kornacki, 2001; Tompkin, 2004). Indicator microorganisms are sensitive to the action of sanitiser, so they can be adequately removed from the environment. Therefore, their presence is mainly due to a reintroduction in the processing environment and they can be referred to as transient
Correspondence: Christian Scarano, Dipartimento di Medicina Veterinaria, Università di Sassari, via Vienna 2, 07100 Sassari, Italy. Tel: +39.079.229454 - Fax: +39.079.229458.

E-mail: scarano@uniss.it

Key words: Farmstead cheese, Shelf-life, Sensory analysis.

Conflict of interests: the authors declare no potential conflict of interests.

Funding: this study was funded and promoted by the Agenzia LAORE Sardegna - Dipartimento per le produzioni zootecniche, Servizio produzioni zootecniche, Sassari, Italy.

Acknowledgments: the authors would like to thank the Agenzia AGRIS Sardegna Dipartimento per la ricerca nelle produzioni animali, Sassari, Italy for their collaboration in the study.

Received for publication: 11 May 2013.

Revision received: 24 July 2013.

Accepted for publication: 24 July 2013.

This work is licensed under a Creative Commons Attribution 3.0 License (by-nc 3.0).

(C) Copyright C. Spanu et al., 2013

Licensee PAGEPress, Italy

Italian Journal of Food Safety 2013; 2:e44

doi:10.4081/ijfs.2013.e44

microflora (Tompkin, 2004). Unlike transient microflora, other microrgansims such as Listeria monocytogenes and Pseudomonas spp. can persist over time established in niches in the food processing environment behaving as resident microflora and serving as a potential source for post-process contamination (ICMS, 2002; Tompkin, 2004). Microbiological characteristics of the product, with particular regard to pathogenic and spoilage bacteria, are essential in order to determine the shelf-life of foods based upon valid scientific evidence. The terms best before date or expiration date are used to define product shelf-life taking into account the deterioration of organoleptic properties of the food. Therefore, when defining the shelf-life of their products, FBOs should conduct, in addition to microbiological testing, also sensory analysis evaluations.

Little research has been conducted to define the hygienic and organoleptic quality of Fruhe cheese produced in Sardinia (Murgia et al., 2009). The aim of the present study was to obtain valuable information to be used in the determination of the shelf-life of farmstead Fruhe cheese. Therefore, the assessment of environmental hygienic and manufacturing condition of four Sardinian farmstead cheesemaking plants was conducted. Determination of microbiological profile and sensory charac- 
teristics of Fruhe cheese during shelf-life was also conducted under the foreseeable distribution, storage and use conditions.

\section{Materials and Methods}

The survey was conducted during the cheese-making season 2012 enrolling four (AD) farmstead artisanal cheese-making facilities manufacturing Fruhe cheese. The farms were selected among those fulfilling the following criteria: willingness to participate the survey, artisanal production, similar manufacturing process, same packaging and product size, distribution of products covering the whole regional territory. Although in Sardinia small ruminants milk production goes from November/December to June/July, Fruhe production goes from February to July only. In order to take into account variation during the cheese-making season, the facilities were visited three times at 2-month-intervals (March, May and July). Fruhe was manufactured in one plant from goat's milk (A), one plant from sheep's milk (B) and two plants from a mixture of ovine and caprine milk (C and D).

\section{Environmental sampling}

During each visit, environmental samples were collected from processing areas and equipment. In order to reflect working condition hygiene, samples collection was performed during production activities. Environmental sampling included food contact surfaces (jars used to pour milk into plastic containers) and non-food contact surfaces (floors, floor drains and shelves) from the cheese-making and warm rooms. Environmental sampling was conducted using sterile sponges pre-moistened with Buffered Peptone Water (3M; St. Paul, MI, USA). Samples were stored at refrigeration temperatures until analysis, which were performed within $24 \mathrm{~h}$ after collection. As a general indication of food-processing hygiene condition, the detection of indicator microorganisms such as Enterobacteriaceae (IS0 21528-1:2004; ISO, 2004a) and E. coli (ISO 16649-1:2001; ISO, 2001) was conducted. The presence or absence of potential resident microflora such as Pseudomonas spp. (ISO/TS 11059:2009; ISO, 2009) and Listeria spp. (UNI EN ISO 112901:2005; ISO, 2005) was also determined.

Presumptive Pseudomonas spp. positive samples were confirmed by molecular identification. After DNA extraction (Cattoir et al., 2010), two different polymerase chain reaction (PCR) protocols were used to identify
Pseudomonas fluorescens (Scarpellini et al., 2004), Pseudomonas spp. and Pseudomonas aeruginosa (De Vos et al., 1997).

\section{Durability study}

Fruhe cheese samples manufactured during each visit were collected the day after they were sealed. The production batches were identified as batch 1, 2 and 3, indicating the cheese produced during the first, the second and the third visit conducted at each farm, respectively. Fruhe cheese samples were transported under refrigeration conditions to the laboratory. Samples were analysed at the following sampling times: T0 (the day of sampling), T7, T14 and T21 (respectively 7, 14 and 21 days after production). According to the foreseen storage condition of storage during shelf-life, the samples were kept refrigerated $\left(4 \pm 2^{\circ} \mathrm{C}\right)$ until analysis. For each sample, microbiological and intrinsic properties analysis such as $\mathrm{pH}$ and water activity $\left(\mathrm{a}_{\mathrm{w}}\right)$ were conducted. Microbiological analysis were conducted according to international standard methods and included the following parameters: aerobic mesophilic bacteria (ISO 4833; ISO, 2003), Enterobacteriaceae (ISO 21528-1; ISO, 2004a), E. coli (ISO 16649-2:2001; ISO, 2001), Listeria monocytogenes (IS0 11290-1/2; ISO 1996, 1998), Pseudomonas spp. (ISO/TS 11059:2009; ISO, 2009), and Bacillus cereus (ISO 7932; ISO, 2004b). Cheese $\mathrm{pH}$ and $\mathrm{a}_{\mathrm{W}}$ were measured using pH meter GLP22 (Crison Instruments, Barcelona, Spain) and water activity meter Aqualab 4TE (Decagon, Pullman, WA, USA), respectively.

\section{Sensory evaluation}

During each visit additional Fruhe samples were collected for sensory analysis, which was performed at the LAORE laboratory. A panel of 30 assessors familiar with basic sensory evaluation techniques was recruited. Sensory properties of Fruhe cheese of the same batch were compared at 14 and 21 days of shelf-life by triangle test (UNI U590A2520:2001; UNI, 2001). Sensory analysis was conducted in 12 separate sessions, one for each of the 4 farms and of the 3 sampling times. Prior to the evaluation, Fruhe samples were cut into pieces of about $70 \mathrm{~g}$, identified by a three digit code, allowed to reach room temperature $\left(20^{\circ} \mathrm{C}\right)$ and randomly distributed to panelists. The forced-choice procedure was used, in which panelists were asked to identify the odd sample (which one of the three samples was perceived to be different as compared to the other two), choosing $=0.05,=0.10$ and $\mathrm{Pd}=40 \%$ the number of corrected responses to determine a significant difference between samples was 15 .

\section{Results}

\section{Environmental contamination}

From the environment of the 4 farmstead cheese making plants 48 samples from nonfood contact surfaces and 12 from food contact surfaces were collected. Listeria monocytogenes and Escherichia coli were never detected. Enterobacteriaceae were recovered in 9 out of $12(75.0 \%)$ floor samples collected from the cheesemaking room and in 6 out of 12 (50.0\%) floor samples in the warm room. Floor drains showed Enterobacteriaceae contamination in 7 out of 12 samples (58.3\%). Enterobacteriaceae were constantly recovered from jars in two farms (D and A), while they were never detected in the other two (B and C). A sporadic contamination of the shelves was detected.

Pseudomonas spp. were recovered in 5 out of $12(41.7 \%)$ floor samples collected from the cheesemaking room and in 7 out of 12 samples (58.3\%) from the warm room. Floor drains showed Pseudomonas spp. contamination in 5 out of 12 samples (41.7\%). Pseudomonas spp. contamination was observed in 4 out of 12 shelf samples $(30.0 \%)$ and in 5 out of 12 (41.7\%) samples food contact surfaces. Molecular identification showed that 40 strains isolated from environmental surfaces were confirmed to belong to the genus Pseudomonas, 17 of which (42.5\%) were identified as Pseudomonas fluorescens. Detailed results of environmental contamination for each target microorganism by farm and sampling site over time are reported in Table 1.

\section{Microbiological profile and intrinsic properties}

A total of 48 Fruhe cheese samples were analysed to assess the presence of background and pathogen microorganisms and for the determination of $\mathrm{pH}$ and $\mathrm{a}_{\mathrm{w}}$. In all analysed samples Listeria monocytogenes, Escherichia coli and Bacillus cereus were always below the detection limit of the methods. Mean aerobic mesophilic bacteria counts $\left[\log _{10}\right.$ colony forming units (CFU) $/ \mathrm{g} \pm$ standard deviation (SD)] ranged between $9.44 \pm 0.85$ at $\mathrm{T} 0$ and $8.43 \pm 0.90$ at T21, showing significant differences $(\mathrm{P}<0.05)$ only in farms $\mathrm{B}$ and $\mathrm{C}$ (Table 2). Enterobacteriaceae were constantly recovered from Fruhe samples collected from farm A and showed a significant decrease $(\mathrm{P}<0.05)$ from T0 to T21 (Table 2). They were never detected in Fruhe samples collected from farm $\mathrm{C}$, while contamination occurred in 8 out of 12 samples (66.7\%) and in 4 out of 12 samples (33.3\%) in farm D and B, respectively. Pseudomonas spp. 
was recovered from two Fruhe samples (one from farm A and 1 from farm D) both samples at T0. Table 3 reports the evolution of $\mathrm{pH}$ and $\mathrm{a}_{\mathrm{W}}$ of Fruhe samples during shelf-life.

\section{Sensory analysis}

Overall, 12 sensory analysis sessions with 30 panelists each were conducted. No significant difference was observed by panelist between Fruhe at 14 and 21 days of shelf-life produced during visit one (in March), while Fruhe samples produced during visit two (in May) showed significant differences in all farms. Triangle test conducted on samples collected during visit three (July) showed significant differences only for farm B, where 17 out of 30 panelists recognised the odd sample. Triangle test results for each session and by farm are reported in Table 4 .

\section{Discussion}

Indicator microorganisms are generally recognised as a good measure of hygienic conditions in food processing environment. Testing for Enterobacteriaceae family, instead of coliforms, provides more accurate information on the correct application of GHP in food processing plants. Enterobacteriaceae are sen-

Table 1. Detection of microflora from environmental samples collected from 4 farmstead cheese-making plants.

\begin{tabular}{|c|c|c|c|c|c|c|c|c|c|c|c|c|c|c|c|c|}
\hline \multirow[t]{2}{*}{ Parameters } & \multirow{3}{*}{$\begin{array}{l}\text { Farmstead } \\
\text { cheese-making plant }\end{array}$} & \multicolumn{6}{|c|}{ Cheesmaking room } & \multicolumn{6}{|c|}{ Warm room } & \multicolumn{3}{|c|}{ Equipment } \\
\hline & & \multicolumn{3}{|c|}{ Floor } & \multicolumn{3}{|c|}{ Floor drain } & \multicolumn{3}{|c|}{ Floor } & \multicolumn{3}{|c|}{ Shelves } & \multicolumn{3}{|c|}{ Jars } \\
\hline & & 1 & 2 & 3 & 1 & 2 & 3 & 1 & 2 & 3 & 1 & 2 & 3 & 1 & 2 & 3 \\
\hline \multirow[t]{4}{*}{ Enterobacteriaceae } & $\mathrm{A}$ & + & + & + & + & + & - & + & + & - & - & - & + & + & + & + \\
\hline & B & - & - & + & - & - & + & - & - & + & - & - & - & - & - & - \\
\hline & $\mathrm{C}$ & + & + & + & + & + & - & + & + & - & - & - & - & - & - & - \\
\hline & D & + & + & - & + & + & - & - & + & - & - & - & - & + & + & + \\
\hline \multirow[t]{4}{*}{ Pseudomonas spp. } & A & + & - & - & $+^{*}$ & - & - & - & - & + & + & + & - & - & + & - \\
\hline & B & + & - & - & $+^{*}$ & - & - & $+^{*}$ & - & + & - & - & - & $+^{*}$ & + & - \\
\hline & C & - & - & $+^{*}$ & - & + & + & $+^{*}$ & + & - & $+^{*}$ & - & - & - & + & - \\
\hline & D & $+^{*}$ & - & + & + & - & - & + & $+*$ & - & + & - & - & $+^{*}$ & - & - \\
\hline
\end{tabular}

1, Samples collected at visit $1 ; 2$, samples collected at visit $2 ; 3$, samples collected at visit $3 ;+$, presence of the target microorganism was observed; -, presence of the target microorganism was not observed. *Pseudomonas fluorescens.

Table 2. Microbiological profile ( $\log _{10}$ cfu $\mathrm{g}^{-1}$;mean \pm standard deviation) of Frube cheese manufactured in 4 farmstead cheese-making plants during shelf-life.

\begin{tabular}{|c|c|c|c|c|c|}
\hline Parameters & Farmstead cheese-making pla & T0 & T7 & T14 & T21 \\
\hline Aerobic mesophilic bacteria & $\begin{array}{l}\text { A } \\
\text { B } \\
\text { C } \\
\text { D }\end{array}$ & $\begin{array}{l}.78 \pm 1.40^{\mathrm{a}}(\mathrm{n}=3 / 3) \\
.25 \pm 0.22^{\mathrm{a}}(\mathrm{n}=3 / 3) \\
.00 \pm 0.27^{\mathrm{a}}(\mathrm{n}=3 / 3) \\
.70 \pm 1.13^{\mathrm{a}}(\mathrm{n}=3 / 3)\end{array}$ & $\begin{array}{c}9.13 \pm 0.22^{\mathrm{a}}(\mathrm{n}=3 / 3) \\
9.29 \pm 0.229^{\mathrm{a}}(\mathrm{n}=3 / 3) \\
8.81 \pm 0.45^{\mathrm{a}}(\mathrm{n}=3 / 3) \\
9.55 \pm 0.36^{\mathrm{a}}(\mathrm{n}=3 / 3)\end{array}$ & $\begin{array}{l}8.96 \pm 0.45^{\mathrm{a}}(\mathrm{n}=3 / 3) \\
8.93 \pm 0.63^{\mathrm{ab}}(\mathrm{n}=3 / 3) \\
7.86 \pm 0.33^{\mathrm{b}}(\mathrm{n}=3 / 3) \\
9.58 \pm 0.23^{\mathrm{a}}(\mathrm{n}=3 / 3)\end{array}$ & $\begin{array}{l}8.17 \pm 0.94^{\mathrm{a}}(\mathrm{n}=3 / 3) \\
8.14 \pm 0.89^{\mathrm{b}}(\mathrm{n}=3 / 3) \\
7.89 \pm 0.43^{\mathrm{b}}(\mathrm{n}=3 / 3) \\
9.52 \pm 0.31^{\mathrm{a}}(\mathrm{n}=3 / 3)\end{array}$ \\
\hline Enterobacteriaceae & $\begin{array}{l}\text { A } \\
\text { B } \\
\text { C } \\
\text { D }\end{array}$ & $\begin{array}{l}.13 \pm 0.86^{a}(n=3 / 3) \\
3.52 \pm 0.00(n=1 / 3) \\
0.0 \pm 0.00(n=0 / 3) \\
.73 \pm 0.09^{a}(n=2 / 3)\end{array}$ & $\begin{array}{c}4.26 \pm 0.33^{\mathrm{ab}}(\mathrm{n}=3 / 3) \\
3.43 \pm 0.00(\mathrm{n}=1 / 3) \\
0.0 \pm 0.00(\mathrm{n}=0 / 3) \\
4.16 \pm 0.06^{\mathrm{ab}}(\mathrm{n}=2 / 3)\end{array}$ & $\begin{array}{c}3.94 \pm 0.29^{\mathrm{b}}(\mathrm{n}=3 / 3) \\
3.01 \pm 0.00(\mathrm{n}=1 / 3) \\
0.0 \pm 0.00(\mathrm{n}=0 / 3) \\
3.33 \pm 0.56^{\mathrm{b}}(\mathrm{n}=2 / 3)\end{array}$ & $\begin{array}{c}2.66 \pm 0.25^{\mathrm{c}}(\mathrm{n}=2 / 3) \\
2.99 \pm 0.00(\mathrm{n}=1 / 3) \\
0.0 \pm 0.00(\mathrm{n}=0 / 3) \\
3.34 \pm 0.00^{\mathrm{b}}(\mathrm{n}=1 / 3)\end{array}$ \\
\hline Pseudomonas spp. & $\begin{array}{l}\text { A } \\
\text { B } \\
\text { C } \\
\text { D }\end{array}$ & $\begin{array}{l}1.36 \pm 0.00(n=1 / 3) \\
0.0 \pm 0.00(n=0 / 3) \\
0.0 \pm 0.00(n=0 / 3) \\
1.51 \pm 0.00(n=1 / 3)\end{array}$ & $\begin{array}{l}0.0 \pm 0.00(n=0 / 3) \\
0.0 \pm 0.00(n=0 / 3) \\
0.0 \pm 0.00(n=0 / 3) \\
0.0 \pm 0.00(n=0 / 3)\end{array}$ & $\begin{array}{l}0.0 \pm 0.00(\mathrm{n}=0 / 3) \\
0.0 \pm 0.00(\mathrm{n}=0 / 3) \\
0.0 \pm 0.00(\mathrm{n}=0 / 3) \\
0.0 \pm 0.00(\mathrm{n}=0 / 3)\end{array}$ & $\begin{array}{l}0.0 \pm 0.00(\mathrm{n}=0 / 3) \\
0.0 \pm 0.00(\mathrm{n}=0 / 3) \\
0.0 \pm 0.00(\mathrm{n}=0 / 3) \\
0.0 \pm 0.00(\mathrm{n}=0 / 3)\end{array}$ \\
\hline
\end{tabular}

The sampling times T0, T7, T14 and T21 refer to the days ( $0,7,14$, and 21, respectively) elapsed during the shelf-life. Means in the same row with different superscript letters are significantly different (P<0.05).

Table 3. Evolution of $\mathrm{pH}$ and $\mathrm{a}_{\mathrm{W}}$ (mean \pm standard deviation) of Frube cheese manufactured in 4 farmstead cheese-making plants during shelf-life.

\begin{tabular}{|c|c|c|c|c|c|c|c|c|}
\hline \multirow{2}{*}{ Farmstead cheese-making plant } & \multicolumn{4}{|c|}{$\mathrm{pH}$} & \multicolumn{4}{|c|}{$\mathbf{a}_{\mathrm{w}}$} \\
\hline & T0 & T7 & T14 & T21 & T0 & $\mathrm{T} 7$ & T14 & T21 \\
\hline A & $4.45 \pm 0.06^{\mathrm{a}}$ & $4.42 \pm 0.10^{\mathrm{a}}$ & $4.39 \pm 0.10^{a}$ & $4.38 \pm 0.06^{\mathrm{a}}$ & $0.986 \pm 0.01^{\mathrm{a}}$ & $0.993 \pm 0.01^{\mathrm{a}}$ & $0.996 \pm 0.00^{\mathrm{a}}$ & $0.994 \pm 0.00^{a}$ \\
\hline B & $4.44 \pm 0.08^{a}$ & $4.50 \pm 0.18^{a}$ & $4.47 \pm 0.16^{a}$ & $4.41 \pm 0.04^{\mathrm{a}}$ & $0.987 \pm 0.02^{\mathrm{a}}$ & $0.993 \pm 0.00^{\mathrm{a}}$ & $0.993 \pm 0.00^{\mathrm{a}}$ & $0.994 \pm 0.00^{\mathrm{a}}$ \\
\hline $\mathrm{C}$ & $4.40 \pm 0.08^{a}$ & $4.44 \pm 0.15^{\mathrm{a}}$ & $4.44 \pm 0.14^{\mathrm{a}}$ & $4.45 \pm 0.14^{\mathrm{a}}$ & $0.988 \pm 0.00^{a}$ & $0.994 \pm 0.00^{a}$ & $0.993 \pm 0.00^{\mathrm{a}}$ & $0.988 \pm 0.00^{\mathrm{a}}$ \\
\hline D & $4.52 \pm 0.05^{\mathrm{a}}$ & $4.56 \pm 0.22^{\mathrm{a}}$ & $4.48 \pm 0.16^{a}$ & $4.45 \pm 0.10^{\mathrm{a}}$ & $0.983 \pm 0.01^{\mathrm{a}}$ & $0.995 \pm 0.00^{\mathrm{b}}$ & $0.994 \pm 0.00^{\mathrm{b}}$ & $0.987 \pm 0.01^{\mathrm{ab}}$ \\
\hline
\end{tabular}

$\mathrm{a}_{\mathrm{w}}$, water activity. The sampling times T0, T7, T14 and T21 refer to the days $(0,7,14$, and 21 , respectively) elapsed during the shelf-life. Means in the same row with different superscript letters are significantly different $(\mathrm{P}<0.05)$. 
Table 4. Triangle test of Frube cheese at 14 and 21 days of shelf-life in three production batches by 30 panelists.

\begin{tabular}{|c|c|c|c|c|}
\hline Farmstead cheese-making plant & Batch* & & orrect & \\
\hline & & Correct answer & $\%$ & Significance \\
\hline A & 1 & $10 / 30$ & 33.3 & NS \\
\hline B & 1 & $9 / 30$ & 30.0 & NS \\
\hline $\mathrm{C}$ & 1 & $10 / 30$ & 33.3 & NS \\
\hline $\mathrm{D}$ & 1 & $12 / 30$ & 40.0 & NS \\
\hline A & 2 & $17 / 30$ & 56.7 & $\mathrm{P}<0.05$ \\
\hline B & 2 & $15 / 30$ & 50.0 & $\mathrm{P}<0.05$ \\
\hline $\mathrm{C}$ & 2 & $16 / 30$ & 53.3 & $\mathrm{P}<0.05$ \\
\hline D & 2 & $18 / 30$ & 60.0 & $\mathrm{P}<0.05$ \\
\hline A & 3 & $9 / 30$ & 30.0 & NS \\
\hline B & 3 & $13 / 30$ & 43.3 & NS \\
\hline $\mathrm{C}$ & 3 & $17 / 30$ & 56.7 & $\mathrm{P}<0.05$ \\
\hline D & 3 & $12 / 30$ & 40.0 & NS \\
\hline
\end{tabular}

NS, not significant. *Batch 1, 2 and 3 correspond to Fruhe production carried out during visit 1 (March), visit 2 (May) and visit 3 (July), respectively.

sitive to sanitiser and heat treatment, therefore they can be effectively used either as indicators of hygiene or of post-heat processing contamination. In the present study, post-operational surfaces showed Enterobacteriaceae contamination to some extent, which is to be expected. For cheese made from milk that has undergone a heat treatment, Enterobacteriaceae are not included in the process hygiene criteria laid down by Regulation (EC) No. 2073/2005 (Euroepan Commission, 2005). However, their frequent recovery in the final product (3 to $5 \log _{10} \mathrm{cfu} / \mathrm{g}$ ) could indicate a failure in the hygienic preparation and handling of Fruhe or that underprocessing occurred, e.g. inadequate pasteurization (FSNZ, 2001). In the two farms where Enterobacteriaceae were constantly recovered from Fruhe cheese samples, a significant decrease of the contamination level was observed over time. It may be explained with the low $\mathrm{pH}(4.45 \pm 0.11)$ of the product which can contribute to the inactivation of these microorganisms.

The Regulation (EC) 2073/2005 (Euroepan Commission, 2005) on microbiological criteria for foodstuffs includes another indicator microorganism, E. coli, as process hygiene criteria for cheese. $E$ coli was never detected in Fruhe samples, indicating compliance of the product with this specific hygiene criteria either at the beginning or at the end of the shelf-life. Another important aspect of environmental monitoring in food processing plants is the detection of pathogen microorganisms such as $L$. monocytogenes. It is well established the ability of Listeria monocytogenes to persist in food processing environment (Carpentier and Cerf, 2011) representing a potential source of food post-process contamination (Tompkin, 1999). In the frame of the EC Regulation 2073/2005 (Euroepan Commission, 2005), sampling programmes to detect the presence of $L$. monocytogenes should be conducted on processing areas and equipment.

In the present study $L$. monocytogenes nor listeria-like organisms were detected on food contact and non-food contact surfaces. This indicates that Fruhe cheese farmstead production seems to be associated with a low risk of Listeria contamination. In the determination of a food shelf-life it is essential to consider whether the product supports or not the growth of $L$. monocytogenes. Ready-to-eat products with $\mathrm{pH} \leq 4.4$ and $\mathrm{a}_{\mathrm{w}} \leq 0.92$ or $\mathrm{pH} \leq 5.0$ and $\mathrm{a}_{\mathrm{W}} \leq 0.94$, and products with shelf-life of less than five days are considered unable to support the growth of $L$. monocytogenes. Fruhe cheese is characterised by $\mathrm{pH}$ ranging from 4.3 to 4.8 and $\mathrm{a}_{\mathrm{W}}$ ranging from 0.983 to 0.996 and shelflife of about two weeks. Therefore, FBOs should demonstrate the compliance with absence in $25 \mathrm{~g}$ criteria before the food has left its immediate control and with the limit of 100 $\mathrm{CFU} / \mathrm{g}$ during the entire shelf-life. Listeria monocytogenes was never detected at each of the sampling time showing compliance with the most restrictive criteria during Fruhe shelf-life. However, more information should be provided on the behaviour of $L$. monocytogenes artificially inoculated in Fruhe cheese samples. Sensory evaluation showed differences between Fruhe cheese samples at 14 and 21 days of shelf-life mostly limited to the production carried out in May and with a number of correct responses observed really close to the expected number (15) of corrected responses required to determine a significant difference between the samples. Overall, the sensory evaluation indicates that none or limited differences exist between the product at 14 and 21 days of shelf-life.

\section{Conclusions}

Farmstead Fruhe cheese production is characterised by a wide operational and post-operational environmental contamination with Enterobacteriaceae indicating the need for good hygiene practice improvement. On the other hand, the absence of pathogenic bacteria such as Listeria monocytogenes, in combination with the sensory analysis, supports a possible extension of Fruhe shelf-life up to three weeks.

\section{References}

Carpentier B, Cerf 0, 2011. Review. Persistence of Listeria monocytogenes in food industry equipment and premises. Int J Food Microbiol 145:1-8.

Cattoir V, Gilibert A, Le Glaunec JM, Launay N, Bait-Mérabet L, Legrand P, 2010. Rapid detection of Pseudomonas aeruginosa from positive blood cultures by quantitative PCR. Ann Clin Microbiol Antimicrob 9:1-5.

De Vos D, Lim A Jr, Pirnay JP, Struelens M, Vandenvelde C, Duinslaeger L, Vanderkelen A, Cornelis P, 1997. Direct detection and identification of Pseudomonas aeruginosa in clinical samples such as skin biopsy specimens and expectorations by multiplex PCR based on two outer membrane lipoprotein genes, oprI and oprL. J Clin Microbiol 35:12958-9.

European Commission, 2004. Commission Regulation of 29 April 2004 on the hygiene of foodstuffs, 852/2004/EC. In: Official Journal, L 139/1, 30/04/2004.

European Commission, 2005. Commission 
Regulation of 15 November 2005 on microbiological criteria for foodstuffs, 2073/2005/EC. In: Official Journal, L 338/1, 22/12/2005

Health Protection Agency. Guidelines for assessing the microbiological safety of ready-to-eat foods, 2009. Health Protection Agency ed., London. Available from: http://www.hpa.org.uk/webc/HPAwebFile/H PAweb_C/1259151921557

ICMS, 2002. Microorganisms in foods, 7. In: International Commission on Microbiological Specifications for Foods, ed. Microbiological testing in food safety management. Kluwer Academic/Plenum Publ., New York, NY.

ISO, 1996. Microbiology of food and animal feeding stuffs-horizontal method for the detection and enumeration of Listeria monocytogenes. Part 1: detection method. ISO Norm 11290-1. International Standardization Organization ed., Geneva, Switzerland.

ISO, 1998. Microbiology of food and animal feeding stuffs-horizontal method for the detection and enumeration of Listeria monocytogenes. Part 2: enumeration method. ISO Norm 11290-2. International Standardization Organization ed., Geneva, Switzerland

ISO, 2001. Microbiology of food and animal feeding stuffs. Horizontal method for the enumeration of -glucuronidase-positive Escherichia coli. ISO Norm 16649.
International Standardization Organization ed., Geneva, Switzerland.

ISO, 2003. Microbiology of food and animal feeding stuffs. Horizontal method for the enumeration of microorganisms: colonycount technique at $30^{\circ} \mathrm{C}$. ISO Norm 4833 . International Standardization Organization ed., Geneva, Switzerland.

ISO, 2004a. Microbiology of food and animal feeding stuffs. Horizontal methods for the detection and enumeration of Enterobacteriaceae. Part 1: detection and enumeration by MPN technique with preenrichment. ISO Norm 21528-1. International Standardization Organization ed., Geneva, Switzerland.

ISO, 2004b. Microbiology of food and animal feeding stuffs. Horizontal method for the enumeration of presumptive Bacillus cereus and colony-count technique at $30^{\circ} \mathrm{C}$. ISO Norm 7932. International Standardization Organization ed., Geneva, Switzerland.

ISO, 2009. Milk and milk products. Method for the enumeration of Pseudomonas spp. ISO/TS Norm 11059:2009 (IDF/RM 225:2009). International Standardization Organization ed., Geneva, Switzerland.

Jay JM, 1992. Modern food microbiology. Microbiological indicators of food safety and quality, principles and quality control, and microbiological criteria. Van Nostrand Reinhold ed., New York, NY, USA.

Kornacki JL, 2001. Enterobacteriaceae, col- iforms, and Escherichia coli as quality and safety indicators. In: Downes FP and Ito K, eds. Compendium of methods for the microbiological examination of foods, 4th ed. American Public Health Association ed., Washington, DC, pp 69-82.

LAORE Sardegna, 2013. Cheeses of Sardinia. Department for the Multifunctionality of Agricultural Enterprises, Rural Development \& Agrifood Chain ed., Cagliari, Italy. Available from: http://www. sardegnaagricoltura.it/documenti/14_43_20091216131002.pdf

Murgia MA, Mangia NP, Fancello F, Deiana P, 2009. Microbiological characterization of Fruhe cheese. Ann Microbiol 59:69.

Scarpellini M, Franzetti L, Galli A, 2004. Development of PCR assay to identify Pseudomonas fluorescens and its biotype. FEMS Microbiol Lett 236:257-60.

Tompkin RB, 2004. Environmental sampling. A tool to verify the effectiveness of preventive hygiene measures. Mitt Lebensmittelunters Hyg 95:45-51.

Tompkin RB, Scott VN, Bernard DT, Sveum WH, Gombas KS, 1999. Guidelines to prevent post-processing contamination from Listeria monocytogenes. Dairy Food Environ Sanit 19:551-62.

UNI, 2001. UNI U590A2520 Norm. [Analisi sensoriale. Metodo triangolare]. [Regulation in Italian]. Italian Unification Institute ed., Milan, Italy. 